\title{
Towards Industry 4.0: Determining Agro-industrial Technology Graduate Competencies in Higher Education
}

\author{
Arief Rahmawan ${ }^{1}$, Mohammad Muslih ${ }^{2}$, Jarman Arroisi ${ }^{3}$, Dwi Rifianto ${ }^{4}$, Adib Fuadi Nuriz \\ arief.rahmawan@unida.gontor.ac.id ${ }^{1}$, muslih@unida.gontor.ac.id², jarman@unida.gontor.ac.id ${ }^{3}$ \\ University of Darussalam Gontor, Jalan Raya Siman Km. 6, Ponorogo, Indonesia ${ }^{1,2,3,4,5}$
}

\begin{abstract}
The emergence of Industry 4.0 has a significant impact for many organizations such as higher education particularly in managing their knowledge of the curriculum. Nowadays, the world has shifted to more advanced technology, and this must be fulfilled by increasing human resources capacity. Meanwhile, many universities are unaware of this transition to re-manage their curriculum of knowledge for better adjustment of core competencies as the stakeholders expected. This research aims to determine the voice of stakeholder from Agro-industrial Technology enterprises by implementing House of Quality Matrix as the main tools. Besides, attempt to identify the main issues of the latest industrial revolution and match graduates' abilities as the company needed. The methodology applied was investigating selected stakeholders by utilizing questionnaire to gather information comprises graduate abilities, graduate competencies and technical skills. To sum up, this article generating customer need which contains Industry 4.0 characteristics as the beginning phase of curriculum design.
\end{abstract}

Keywords: Curriculum, Knowledge Management, Learning Outcomes, Quality Function Deployment

\section{Introduction}

Nowadays, the world has been entering a new era namely Industry 4.0 which began in Germany formally by the Federal Ministry of Education and Research in the year 2010. The terminology of Industry 4.0 or commonly named as the fourth industrial revolution was referring to the continued industrial development since began in the middle of the $18^{\text {th }}$ century as the first pioneer industrial mechanization era. Many scholars attempted to analyze this latest manufacture revolution whether it wanted or not and what was the implication for society. For instance, the emergence of Smart Manufacturing (SM) shall fit Small and Medium-sized Enterprises (SMEs) particular requirements by yielding maturity model and determining assessment toolkit to develop their vision and roadmap [1].

On the other hand, utilization of Smart Industry elements such as industrial internet, cloud computing, big data, industrial network security and 3D prototyping are successfully implemented in the food industry by utilizing mass customization model [2]. Those elements are defined as the 
core platform of SM that already in the industry. The necessity of connection and integration between management function, production lines, suppliers and customers somehow will be more in sophisticated ways, and smart manufacturing is one of the promising solutions. Meanwhile, some developed countries have been intrigued to gradually accelerate the transformation of future manufacturing such as Japan with the concept of Society 5.0 strategy, China with manufacturing 2025 and Europe 2020 strategy. Eventually, we have to embrace this phenomenon rather than denying the great purpose of humankind.

Future industries are originally digitalized, and decentralized organization functions through the network platform. The output of the future industry is the so-called smart product, refers to the new generation of physical product embedded with the particular sensor to collect, transmit and transfer data to the environment. Furthermore, the smart industry is the shifting from traditional to digital and intelligent enterprises as the service orientation by utilizing interconnectivity between factory and network technology such as Industrial Internet of Things (IIoT) and Cyber-Physical Production System (CPPS). More importantly, the smart factory is defined as the integration of physical resources and human resources through IIoT. In the context of intelligent manufacturing, it is essential that human resource as the paramount assets in the industry must respond adequately to proficient on these technologies. Within the fourth industrial revolutions, automated manufacture and robotics will sorely impact job opportunities in most future-oriented enterprises. It can be appointed that the enormity of Industry 4.0 will influence the particular fulfilment prowess in employee recruitment. Scholars argued whether future manufacturing more likely creating the job than diminish the job, particularly in computer engineering, artificial intelligence, cloud engineering and so forth. To fulfil this position, the job applicants must be eligible to meet enterprises requirement to do their job in digitizing production lines.

The education system needs to be redesigned to meet the updated concept of Factory 4.0 and manufacturer as the stakeholders of universities. More importantly, higher education institution plays an essential role to produce their alumni as current industry needed. Many researchers have been encouraging to propose a scientific model in terms of transferring stakeholder need through curriculum design in a higher education institution. For instance, There were strong relationships between graduate abilities and core competencies by the implementation of the house of quality [3] in the Agro-industrial Technology Department, University of Darussalam Gontor Indonesia. Similarly, the industry-oriented framework was proposed as the education method to embrace dynamically changing employment needs of industry, which comprises degree internships, start-up focus degrees, tailored studies and various significant related with Industry 4.0 elements [4]. Also, it is crucial for the government in developing countries must encourage societies to have creativity in the business model as well as innovation in terms of social development. Socio-cultural institutional transformation is a strategic objective of the Thailand government facing the age of the fourth industrial revolution [5]. Thailand government attempts to propose economic development such as emphasize agricultural sector and transform into a value-based and innovation-driven economy. The identification of industry 4.0 current research paper had been conducted by implementing a structured literature review and yielding sustainable industry 4.0 framework. Current research categorized particular paper namely concept of industry 4.0; machine-equipment interactions; human-machine interactions; sustainability and trend technology of industry 4.0 [6]. Eventually, the world must accelerate their knowledge for better understanding of advanced 
technology and the only possible is through curriculum design in many level education institutions, particularly in universities/colleges.

As an emerging institution, University of Darussalam (UNIDA) Gontor, particularly Department of Agro-industrial Technology attempts to respond to the phenomenon of Industry 4.0. Also, the rapid development of advanced technology has emphasized industries to demand qualified higher educated employees more creative and innovative. The main problem is industries lacks involvement in the higher education system, in terms of designing curriculum which embedded knowledge, skills and competencies. Similarly, UNIDA Gontor has to respond immediately to provide eligible graduates who possess technical skills as enterprises needed. Furthermore, this research is aimed to identify several critical issues of Industry 4.0 technology and analyze skill and knowledge from the stakeholders' perspective. More importantly, gathering information such as graduate abilities from selected industries which already have Memorandum of Understanding (MoU) with the Agro-industrial Technology Department are needed. Further, one of renowned total quality management, namely House of Quality is applied by utilizing relationships submatrix to gain the degree between crucial issues and relevance knowledge. Moreover, the objective of this research is to conceptualize better curriculum materials of Agro-industrial Technology department so they can prepare their graduates to work in future manufacturing and to understand the human-machine interface.

\section{Literature Review}

\subsection{Design Principles of Industry 4.0}

Last three industrial revolutions have transformed the manufacturing substantially from a steam machine to advance automated digital machine. It was pioneered by Germany in 2011 and introduced to the public through German Engineering Federation at the Hannover Messe. Additionally, Germany strategy to implement their roadmap is maintaining its production at home to serve the international market and enhance employee skill to support their export products. German Standardization Roadmap on Industry 4.0 is mainly discussed about the detail of semantic and ontological linkage with the administration shell and Industry 4.0 components in the future [7]. This roadmap has led by Federal Ministry for Economic Affairs and Energy (BMWi) and Federal Ministry of Education and Research (BMBF), with the involvement of three significant industry associations, those are BITKOM, VDMA and ZVEI. Together they formulated a platform of Industry 4.0 comprehensively to ensure that Industry 4.0 solutions are implemented on a global scale. Also, Germany also considers from many levels of standardization from national through international to geared toward globally.

Many scholars, practitioners and societies are unclear about the term of Industry 4.0, encountering the difficulties of how to implement this development. Moreover, manufacturing is encountering difficulties to understand the requirement of transition toward smart manufacturing. Scholars believe the concept of Factory 4.0 has led to significant development in technological innovation. According to the current researches, many academicians categorized and explain the terminology of Industry 4.0 and addresses its issues. Figure 1. depicts the main design principles of Industry 4.0 according 
to [8] which comprised 12 design principles and 14 technology trends. For a better understanding of those elements will be summarized in Table 1.

Fig 1. Technology Trends of Industry 4.0 [8]

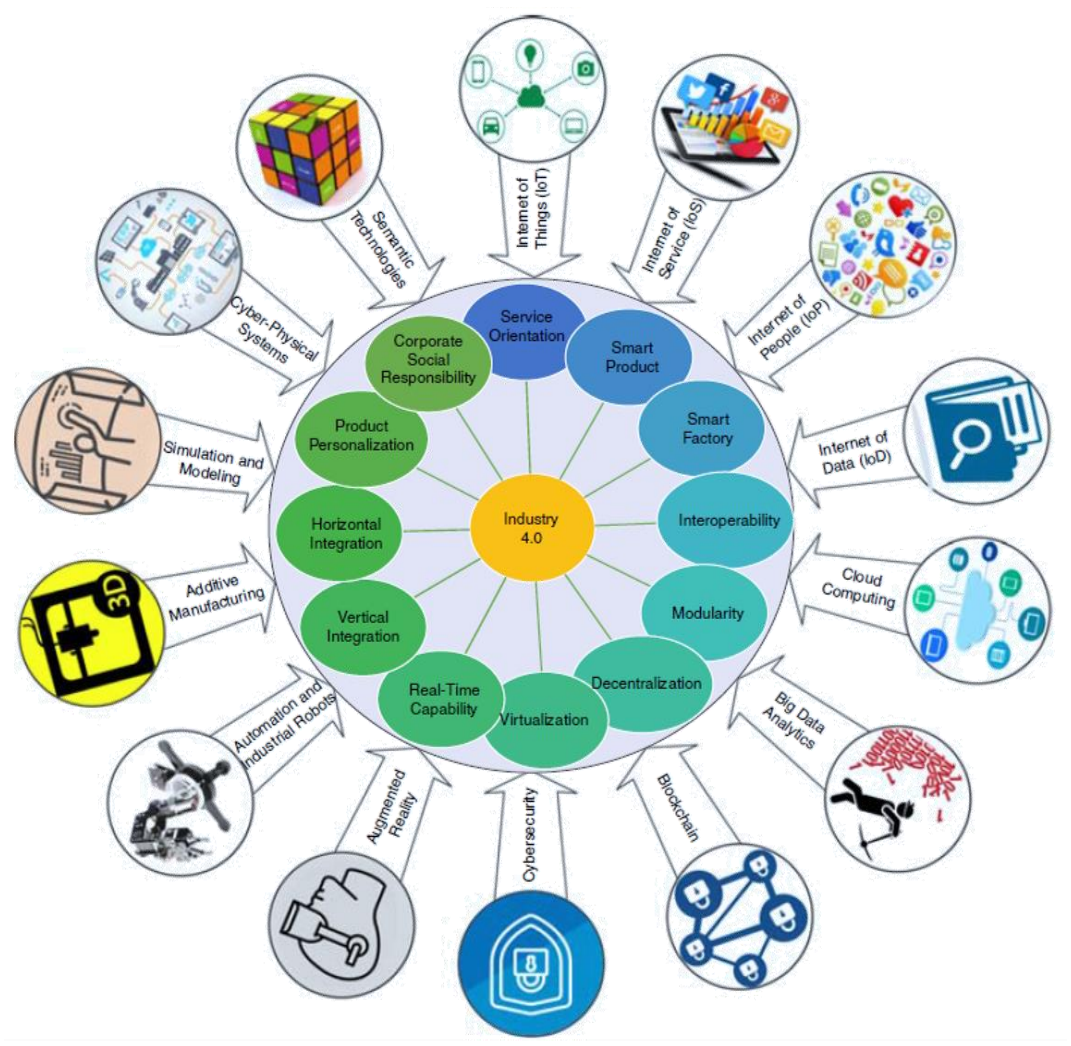

\subsection{Toward Indonesia 4.0}

As an emerging country, Indonesia has a tremendous opportunity to revitalize the industrial sector to be the top 10 largest economies by 2030. The government through the Ministry of Industry reported, in 2016 the manufacturing sector had contributed $20 \%$ of product domestic product (PDB) [9]. Importantly, the Indonesian Minister of Industry formulated National Industrial Committee to carry out ten national priorities as the goal to implement the Fourth Industrial Revolution. Those ten priorities comprise: (1) reform material flow (2) redesign industrial zones (3) embrace sustainability (4) empower SMEs (5) build nationwide digital infrastructure (6) attract foreign investors (7) upgrade human capital (8) establish innovation system (9) incentivize technology investment and (10) re-optimize regulations and policies. Improvement the human resource skills and competencies shall be the initial step via matching program between education and industry. To achieve that, 
Minister of Research, Technology and Higher Education must embrace universities, institutes and colleges to state their educational program.

Table 1. Characteristics of technology trends [1], [8], [10], [11]

\begin{tabular}{|c|c|}
\hline Technology Trends & Characteristics \\
\hline Internet of Things (IoT) & $\begin{array}{l}\text { - As the supporting technology of smart machines excel } \\
\text { humans at precisely and constantly capturing and } \\
\text { communicating data } \\
\text { - As well as the integration of cyber-physical process } \\
\text { which supported with sensors and compatible network } \\
\text { - In the context of industry, can be referred to as Industrial } \\
\text { Internet of Things (IIoT) }\end{array}$ \\
\hline Internet of Services (IoS) & $\begin{array}{l}\text { Defined as utilizing the internet for an innovative way } \\
\text { of value creation through Product as a Service (PaaS) } \\
\text { business model } \\
\text { - Embedded infrastructure with sensor-based products to } \\
\text { give some information such as product usage and its } \\
\text { condition }\end{array}$ \\
\hline Internet of People (IoP) & $\begin{array}{l}\text { Refers to humans become an active element of the internet. } \\
\text { For instance, humans put their personal information online } \\
\text { and make virtual public communication about their feelings }\end{array}$ \\
\hline Internet of Data (IoD) & $\begin{array}{l}\text { - Effective data to transferred, stored, managed and } \\
\text { processed into the system } \\
\text { - Database management systems to serve IoT, IoS and IoP }\end{array}$ \\
\hline Cloud Computing & $\begin{array}{l}\text { - Effective technology to reduce IT infrastructure which } \\
\text { utilizes computing resources when using any device } \\
\text { connected to the internet } \\
\text { Enable the integration of distributed manufacturing } \\
\text { resources and flexible infrastructure across } \\
\text { geographically }\end{array}$ \\
\hline Big Data Analysis & $\begin{array}{l}\text { - Specific technologies with new analytical methods and } \\
\text { tools to transform the substantial volume of data } \\
\text { effectively and efficiently into information and } \\
\text { knowledge }\end{array}$ \\
\hline Blockchain & $\begin{array}{l}\text { - Foundation of cryptocurrencies, enable countless smart } \\
\text { devices to perform the transparent, secure, fast and } \\
\text { smooth financial transaction in the IoT platform } \\
\text { - It can be utilized in any digitized transfer of information, } \\
\text { develop a trusted relationship between suppliers, } \\
\text { manufacturers and customers }\end{array}$ \\
\hline Cyber Security & $\begin{array}{l}\text { Techniques aimed to protect critical industrial systems, } \\
\text { manufacturing lines and database from unauthorized access }\end{array}$ \\
\hline
\end{tabular}




\begin{tabular}{ll}
\hline \multicolumn{1}{c}{ Technology Trends } & \multicolumn{1}{c}{ Characteristics } \\
\hline Augmented Reality & $\begin{array}{l}\text { A digital interface by placing a virtual object in the real world, } \\
\text { to give a higher calculation of perception using various } \\
\text { technology } \\
\text { As the visualization of computer graphics in the real } \\
\text { environment }\end{array}$ \\
Automation and Industrial & $\begin{array}{l}\text { Future manufacture will employ robot which able to } \\
\text { communicate, adapt and react } \\
\text { Robots }\end{array}$ \\
Human-machine interaction becomes more intensive in many \\
organization functions such as production, distribution, \\
maintenance etc. \\
The reflection of technologies to develop three-dimensional \\
objects layer by layer under computer control
\end{tabular}

\section{Methodology}

This study initiated with literature review from reputable journals such as Emerald Insight, Science Direct, SAGE, IEEE and Taylor Francis which focus on Industry 4.0 scenario. Those articles taken from many journals were assessed qualitatively. Subsequently, determining critical issues of Industry 4.0 are essential to a better understanding of what are the essential of fourth industrial revolutions.

Meanwhile, gathering some information form selected stakeholders is paramount considering the Department of Agro-industrial Technology has signed several MoU with industries. To comply with this phase, a questionnaire was designed and aimed to yield three primary information comprise graduate abilities, skills and knowledge. Since established in 2014, Department of Agro-industrial Technology has been cooperated approximately with 25 institutions covered universities, industries and local government. Both online and offline questionnaire was prepared to gather data effectively and efficiently. Figure 2. illustrate the steps of research consist of three main phases and the goal is prioritizing knowledge in Agro-industrial Technology curriculum. 


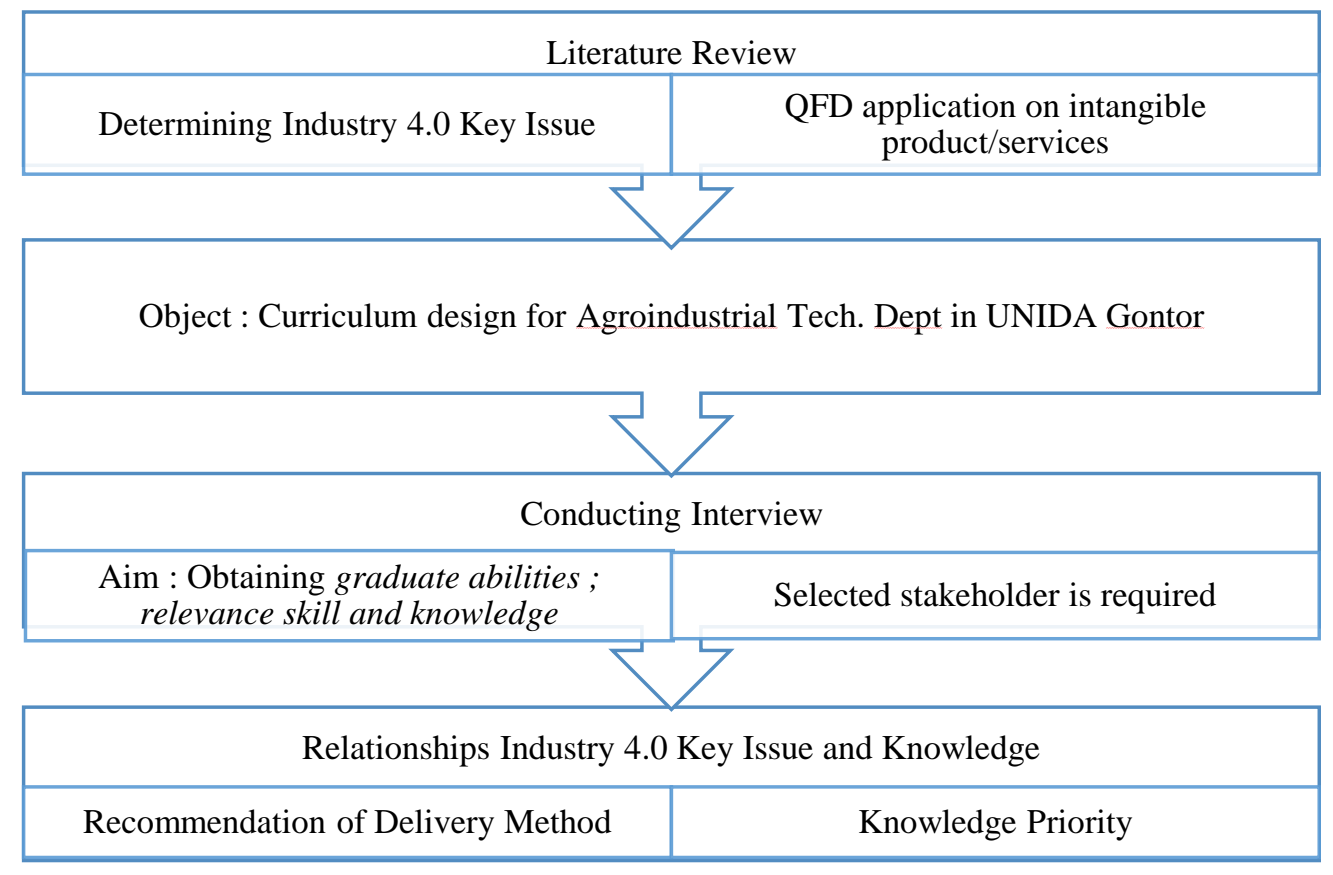

Fig 2. Research methodology

\section{$4 \quad$ Findings}

According to literature reviews in selected papers from notable publishers, some critical issues of industry 4.0 were generated five elements as follows:

1) A new paradigm of manufacturing

Industry 4.0 has shifted the paradigm to the concept of manufacturing. Sustainable manufacturing is needed, and it requires a system thinking approach in all operations of the organization. Complex interactions between human and machines, stages of manufacturing such as additive manufacturing, responsive manufacturing, cloud manufacturing and knowledge-driven manufacturing [12].

2) Business Strategy

Digitization consists of a technology-based driver, namely instrumented, interconnected and utilize intelligently. Digitization and industry 4.0 transition requires the full commitment of top management and fundamental resource allocation. By digitization, functional needs and priorities in all aspects of organizations should be identified, managed and facilitated. 
Nowadays, products derived from the manufacturer are more personalized, so the market business strategy has to change by this condition.

3) Advance Technology

Fourth Industrial Revolution is inseparable from technological progress and its characterized on vertical integration, horizontal integration and end-to-end engineering. Integration between production and management levels [12]. Meanwhile, horizontal integration refers to the collaboration between a functional organization with resource and real-time exchange. Endto-end engineering defined an entire product life cycle from its development until after-sales. On the other hand, technology trends have tremendously impacted the evolution of the smart factory, and many researchers have attempted to identify, review and analyze them.

4) Smart Supply Chain

The emergence of mass-personalization business model, the concept of production will highly be customized that require configuration of the entire supply chain network. This condition will encourage to create digital supply chain network to achieve real-time communication among partners (supplier, manufacturer, customer). According to [13] one of the influence factor to support the digital supply chain is real-time information and technology. Similarly, Industry 4.0 integrated with smart supply chain management (SSCM) allows to access data from operations and business systems, as well as from buy-side partners and sell side partners. Besides, SSCM characteristics comprise collaborations focus, environmental focus, social focus and production system focus.

\subsection{Voice of Stakeholders}

Questionnaires were disseminated among selected stakeholders, yielding the graduate abilities as seen in Table 2. According to [3] there were twelve primary graduate abilities (GA) to be possessed in the department and rank contribution was given. The lower the value of rank contribution indicates graduate users demand that ability. In contrast, the higher the value denotes companies are less need that ability. This information prominently attracts university particularly department to modify their delivery method in lecturing course. Addressing graduate ability seems likely more suitable in the practical field study.

On the other hand, Table 3. summarize required knowledge which classified into four main topics namely (1) Environmental and Management (2) Engineering System and Business Strategy (3) Food, Technology and Process and (4) Agriculture and Animal Husbandry. Considering the types of stakeholders are varying, the topic of Animal Husbandry still relevance with Agro-industrial Technology Department. In the topic of Environmental and Management, dominant topic comprises management scholars, while Halal System becomes a trending topic to be discussed in the class. Additionally, halal is the promising topic for academicians, enterprises and society in many aspects such as industries, tourism and lifestyle. Notably, the particular topic of smart supply chain management shall be given by the development of Industry 4.0. 
Table 2. Graduate abilities rank contribution

\begin{tabular}{clc}
\hline Label & \multicolumn{1}{c}{ Graduate Abilities } & Rank Contribution \\
\hline GA-1 & Teamwork & 4 \\
GA-6 & Problem Solver & 4 \\
GA-5 & Leadership & 4 \\
GA-7 & Logical, critical and analytical thinking & 5 \\
GA-4 & Initiative and Creative & 5 \\
GA-8 & Demonstrate independent, sustainable and & 7 \\
& quality performance & \\
GA-12 & Master in Agro-industrial Technology & 8 \\
& knowledge & 8 \\
GA-2 & Oral presentation & 8 \\
GA-11 & Expertise in Integration of Islam knowledge & 8 \\
& & 8 \\
GA-3 & Proficient in English speaking & 9 \\
GA-9 & Expert in analysis tools & \\
GA-10 & Excellence business plan maker & \\
\hline
\end{tabular}

Table 3. Knowledge requirement by stakeholders

\begin{tabular}{ll}
\hline Topic & \multicolumn{1}{c}{ Knowledge } \\
\hline Environmental and management & Production management \\
& Financial management \\
& Human resource management \\
& Operations management \\
& Supply chain management \\
& GMP, HACCP, ISO 9001 \& 22000 \\
& Cleaner Production \\
& Quality management system \\
& Project management \\
& Halal system \\
& Social community Empowerment \\
& Environmental management \\
& Hygiene \\
& Materials management \\
& Marketing Management \\
& Plan Layout \\
\hline Engineering system and business strategy & Principle of manufacture \\
& Data processing \\
& Planning Inventory \\
& Business Role \\
& Business plan \\
\hline
\end{tabular}




\begin{tabular}{ll}
\hline & Creative industry \\
& Research methodology \\
& Research and Development \\
& Regulations \\
& Process Engineering \\
& New product development \\
& Quality assurance \\
& Optimization of Industry \\
& Entrepreneurship \\
& Upstream and downstream industry \\
& Local wisdom product \\
& Partnership \\
& The innovation of featured product from local society \\
\hline Food, technology and process & Agriculture materials processing \\
& Agriculture Waste Processing Agroindustry ingredient \\
& knowledge \\
& Planning Control Process \\
& Chemical Industry \\
& Microbiology and Chemical \\
& Agroindustry raw materials knowledge \\
& Packaging and Design \\
Food Innovation \\
Food Processing Technology \\
Food Industry Knowledge \\
Food Ingredient \\
Food quality \\
Food quality assurance \\
Food safety \\
Production Process \\
Optimum analysis of Agroindustry development \\
Dairy production \\
Planting, fertilizing, pulverization, harvesting \\
\hline
\end{tabular}

\section{Conclusions}

The rapid development of Industry 4.0 is inevitable. Higher education must provide a response to this change by re-modify their curriculum design in course level, lecture delivery method and enhancing institutional capacity to cooperate with the overseas institution. Moreover, both university and industry must collaborate intensively by grant more occasion to the student. This paper identifies the critical issues of Industry 4.0 and perspective from stakeholders about current ability and knowledge required. Further, this research considered as the early phase of redesigning curriculum comprehensively. Eventually, in-depth research and analysis to obtain appropriate core competencies as relevance with Industry 4.0 are needed. 
Acknowledgement. This research was fully funded by University of Darussalam Gontor, Indonesia. This paper was presented at $1^{\text {st }}$ International Conference on Business, Law and Pedagogy (ICBLP), Sidoarjo, Indonesia.

\section{References}

[1] S. Mittal, M. A. Khan, D. Romero, and T. Wuest, "A critical review of smart manufacturing \& Industry 4.0 maturity models: Implications for small and medium-sized enterprises (SMEs)," J. Manuf. Syst., vol. 49, no. June, pp. 194-214, 2018.

[2] J. Simon, M. Trojanova, J. Zbihlej, and J. Sarosi, "Mass customization model in food industry using industry 4.0 standard with fuzzy-based multi-criteria decision-making methodology," $A d v$. Mech. Eng., vol. 10, no. 3, pp. 1-10, 2018.

[3] A. Rahmawan and M. N. Kholis, "Implementation of Quality Function Deployment ( QFD ) in Agro-industrial Technology curriculum," Agroindustrial Technol. J., vol. 01, no. 01, pp. 1021, 2017.

[4] S. Venkatraman, T. de Souza-Daw, and S. Kaspi, "Improving employment outcomes of career and technical education students," High. Educ. Ski. Work. Learn., vol. 8, no. 4, pp. 469483, 2018.

[5] P. Buasuwan, "Rethinking Thai higher education for Thailand 4.0," Asian Educ. Dev. Stud., vol. 7, no. 2, pp. 157-173, 2018.

[6] S. S. Kamble, A. Gunasekaran, and S. A. Gawankar, "Sustainable Industry 4.0 framework: A systematic literature review identifying the current trends and future perspectives," Process Saf. Environ. Prot., vol. 117, pp. 408-425, 2018.

[7] DIN, "German Standardization Roadmap: Industry 4.0 - Version 3," Ger. Standardization Roadmap Ind. 4.0, 2018.

[8] M. Ghobakhloo, "The future of manufacturing industry: a strategic roadmap toward Industry 4.0," J. Manuf. Technol. Manag., vol. 29, no. 6, pp. 910-936, 2018.

[9] Kementerian Perindustrian, "Making Indonesia 4.0." 2018.

[10] V. Alcácer and V. Cruz-Machado, "Scanning the Industry 4.0: A Literature Review on Technologies for Manufacturing Systems," Engineering Science and Technology, an International Journal, 2019.

[11] L. Ardito, A. M. Petruzzelli, U. Panniello, and A. C. Garavelli, "Towards Industry 4.0: Mapping digital technologies for supply chain management-marketing integration," Business Process Management Journal, 2018.

[12] L. S. Dalenogare, G. B. Benitez, N. F. Ayala, and A. G. Frank, "The expected contribution of Industry 4.0 technologies for industrial performance," Int. J. Prod. Econ., vol. 204, no. July, pp. 383-394, 2018.

[13] E. Manavalan and K. Jayakrishna, "A review of Internet of Things (IoT) embedded sustainable supply chain for industry 4.0 requirements," Comput. Ind. Eng., vol. 127, no. November 2017, pp. 925-953, 2018. 